\title{
Pemetaan Tafsir Aspek Kecenderungan (Aliran) Dalam Khazanah Islam Klasik
}

\section{Abdul Syukkur \\ Sekolah Tinggi Ilmu Ushuluddin (STIU) Al-Mujtama' Pamekasan Abdulsyukkur83@gmail.com}

\begin{abstract}
Abstrak: Al-Qur'an merupakan kitab suci yang șālih li kulli zamānin wa makānin, hal ini tidak lepas dari nilai-nilai universal yang terkandung di dalamnya. Sehingga pantas jika kitab suci ini kemudian menjadi inspirator bagi gerakan dan dinamika umat Islam sepanjang sejarah perkembangannya. Para intelektual Muslim berusaha untuk berinteraksi dan menjadikan al-Qur'an sebagai pedoman hidup, bahkan ada yang menjadikannya sebagai legitimasi terhadap faham, keyakinan, dan tindak-tanduk kehidupanya seharihari. Karena mereka membekali pemahamannya tentang al-Qur'an dengan ilmu yang paling dikuasainya tanpa memperhatikan ilmuilmu yang lain. Artikel ini mengkaji pengertian tafsir dan kecenderungan (aliran), membahas mengenai aliran-aliran yang ada dalam kajian tafsir. Dalam hal ini penulis hanya membatasi pembahasan mengenai aliran yang memiliki pengaruh sangat besar dalam kajian tafsir, yaitu, aliran Sunni, Shi'ah dan Muktazilah, dengan tanpa menafikan keberadaan aliran-aliran lain yang sedikit banyak memiliki sumbangsih pula dalam kajian tafsir, latar-belakang munculnya aliran-aliran tersebut, tokoh-tokohnya, karya-karyanya, metode tafsirnya, kelebihan dan kekurangannya, contoh penafsiran menurut masing-masing aliran, dan tentu saja disertai dengan analisis penulis sendiri terhadap masing-masing penafsiran tersebut.
\end{abstract}

Kata kunci: Tafsir, Aspek Kecenderungan, khazanah Islam.

\section{Prolog}

Al-Qur'an merupakan kitab suci yang șālih li kulli zamānin wa makānin (selalu relevan untuk setiap zaman dan tempat), hal ini tidak lepas dari nilai-nilai universal yang terkandung di dalamnya. Sehingga benar ungkapan yang dinyatakan oleh Hasan Hanafi bahwa, al-Qur'an benar-benar bukan hanya menempati posisi sentral dalam perkembangan dan pengembangan ilmu-ilmu keislaman, tapi juga

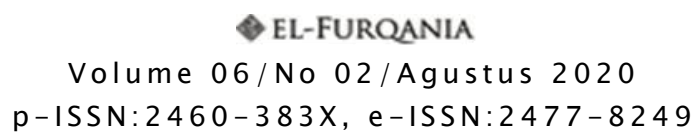


menjadi inspirator bagi gerakan dan dinamika umat Islam sepanjang kurang lebih empat belas abad yang lalu. ${ }^{1}$

Tidak heran bila kemudian muncul berbagai macam cara yang dilakukan oleh para intelektual Muslim untuk mendekati al-Qur'an, karena masing-masing dari mereka ingin berinteraksi dan menjadikan al-Qur'an sebagai pedoman hidup, bahkan tidak jarang yang menjadikannya sebagai legitimasi terhadap faham, keyakinan, dan tindak-tanduk kehidupanya sehari-hari. Mannā' al-Qațān menggambarkan, sehingga para mufassir dalam menafsirkan alQur'an berpegang pada pemahaman pribadi dan mengarah ke berbagai kecenderungan. Pada diri mereka melekat istilah-istilah ilmiah, akidah madhhabi dan pengetahuan falsafi. Masing-masing mufassir memenuhi tafsirnya hanya dengan ilmu yang paling dikuasainya tanpa memperhatikan ilmu-ilmu yang lain. ${ }^{2}$

Hal ini kemudian berdampak pada perbedaan pandangan mengenai penafsiran suatu ayat, bahkan lebih mendasar lagi, para ilmuan berbeda dalam mendefinisikan al-Qur'an itu sendiri. Misalnya, kaum teolog, cenderung mendifinisikannya dari sudut pandang teologis, seperti Khulābiyah, Ash'āriyah, Karāmiyah, Māturidiyah dan penganut sifatiyyah lainnya, menyebut: "Al-Qur'an ialah Kalam Allah yang qadim tidak makhluk". ${ }^{3}$

Sebaliknya kaum Jahmiyah, Muktazilah dan lain-lain yang menganut paham bahwa Tuhan tidak mempunyai sifat, menyatakan bahwa al-Qur'an ialah "makhluk (tidak qadim)". ${ }^{4}$ Sementara itu kaum filosof dan al-Sabi'ah, melihat al-Qur'an dari sudut pandang filosofis. Itulah sebabnya mereka berpendapat bahwa al-Qur'an ialah "makna yang melimpah kepada jiwa".

Perbedaan seperti ini hanya contoh kecil dari dampak perbedaan yang ditimbulkan oleh perbedaan latar belakang keilmuan, dan barangkali "kepentingan" mufassirnya dalam memahami alQur'an. Di sinilah letak pentingnya pembahasan ini, yaitu

\footnotetext{
${ }^{1}$ Hasan Hanafi, al-Yamīn wa al-Yasār fì fikr al-Dīnī, Kairo: Madbūili, 1989), 7.

${ }^{2}$ Mannā' Khalil al-Qaț̣ān, Studi-studi Ilmu al-Qur'an, trj. Mudzakir AS., (Jakarta: Litera Antarnusa, 2001), Cet. 6, Hal. 477.

${ }^{3}$ Al-Shahrastāni dalam Nashruddin Baidan, Wawasan Baru Ilmu al-Qur'an, (Yogyakarta: Pustaka Pelajar, 2011), 15.

${ }^{4}$ Abd al-'Azīz Muhammad Salmān dalam Nashruddin Baidan, Wawasan Baru Ilmu al-Qur'an, (Yogyakarta: Pustaka Pelajar, 2011), 15.

${ }^{5}$ Ibid.
} 
mengetahui lebih jauh mengenai tafsir dari aspek kecenderungan (aliran) mufassirnya.

Makalah ini memuat pembahasan tentang pengertian tafsir dan kecenderungan (aliran), membahas pula mengenai aliran-aliran yang ada dalam kajian tafsir, dalam hal ini penulis hanya membatasi pembahasan mengenai aliran yang memiliki pengaruh sangat besar dalam kajian tafsir, yaitu, aliran Sunni, Shi'ah dan Muktazilah, dengan tanpa menafikan keberadaan aliran-aliran lain yang sedikit banyak memiliki sumbangsih pula dalam kajian tafsir, latar-belakang munculnya aliran-aliran tersebut, tokoh-tokohnya, karya-karyanya, metode tafsirnya, kelebihan dan kekurangannya, contoh penafsiran menurut masing-masing aliran, dan tentu saja disertai dengan analisis penulis sendiri terhadap masing-masing penafsiran tersebut

\section{Pengetian Tafsir dan Kecenderungan (Aliran)}

Pengertian tafsir menurut bahasa memiliki beberapa makna, yaitu keterangan (al-ị̣̂h) dan penjelasan (al-bayān) ${ }^{6}$ menerangkan dan menyatakan, ${ }^{7}$ al-bayān wa al-kashfu (menjelaskan dan mengungkap), ${ }^{8}$ al-ibānah wa kashf al-mughti (menjelaskan dan menyingkap sesuatu yang tertutup). ${ }^{9}$ Dalam kitab Lisān al-Arab, tafsir adalah al-fasr, al-bayān yang memiliki arti keterangan dan memberi penjelasan. Fassara al-shaia berarti abānah $\bar{u}$ yaitu menjelaskan. Lebih lanjut dalam kitab ini juga dijelaskan bahwa tafsir adalah kashfu al-murād 'an al-lafżi al-mushkili (mengungkap arti yang dimaksud dari lafadz yang sulit. ${ }^{10}$

Sedangkan Tafsir secara istilah adalah ilmu untuk mengetahui kandungan kitab Allah yang diturunkan kepada Nabi Muhammad saw., dan penjelasan maknanya serta mengambil hukum dan hikmahhikmahnya. ${ }^{11}$

\footnotetext{
${ }^{6}$ Al-Zahabì, al-Tafsìr wa al-Mufassirūn, (Kairo: Dār al-Hadith, 2005), 17.

${ }^{7}$ M. Hasbi al-Shiddieqy, Sejarah dan Pengantar Ilmu al-Qur' an/Tafsir. (Jakarta: Bulan Bintang, 1954). 178.

8 Jalāluddìn al-Suyūṭì, al-Itqān fí 'Ulūm al-Qur'ān, (Beirut: Dār al-Ma'rifah, t.th), 221.

${ }^{9}$ Mannā' Khalil al-Qatțān, Studi-studi Ilmu al-Qur'an, trj. Mudzakir AS., (Jakarta: Litera Antarnusa, 2001), Cet. 6, Hal. 455.

${ }^{10}$ Ibn Manzūr al-Ifrịqi, Lisān al- 'Arab. (Beirut: Dār al-Fikr, 1990), 55.

${ }^{11}$ M. Ađì al-Ṣābūnī, al-Tibyān fì 'Ulūm al-Qur'ān, Terj. M. Choirul Umar (Bandung: PT. al-Ma’āirif, t.th.), 203.
} 
Al-Zarkāshì mendefinisikan tafsir secara terminologi dengan ilmu yang bertujuan untuk mengetahui tentang kitab Allah yang turun kepada Nabi Muhammad saw., menjelaskan maknanya, menjelaskan hukum-hukum dan hikmahnya. ${ }^{12}$

Sementara Abu Hayyān mendefinisikan tafsir dengan ilmu yang membahas tentang cara pengucapan lafadh-lafadh Qur'an, tentang petunjuk-petunjuknya, hukum-hukumnya, baik ketika berdiri sendiri maupun ketika tersusun dan makna-makna yang dimungkinkan baginya ketika tersusun serta hal-hal lain yang melengkapinya. ${ }^{13}$

Kecenderungan berasal dari kata cenderung yang dalam KBBI berarti menaruh minat (keinginan, kasih, dsb) kepada; suka (ingin) akan. Sementara kecenderungan sendiri berarti kecondongan (hati); kesudian; keinginan (kesukaan) akan sesuatu. ${ }^{14}$ Dari arti ini jika dikaitkan dengan dunia penafsiran maka kecenderungan mufassir akan mengandung arti kecondongan hati seorang mufassir dalam menafsirkan al-Qur'an.

Maksud dari pengertian ini akan lebih jelas lagi bila menggunakan aliran, yang dalam KBBI, aliran mengandung arti haluan; pendapat; paham (politik, pandangan hidup, dsb); politik; falsafah modern. ${ }^{15}$ Maknanya adalah pendapat atau faham mufassir yang terkandung dalam penafsirannya, atau dengan kata lain, pengaruh faham mufassir terhadap penafsiran al-Qur'an.

Sangat sulit membedakan keduanya karena jika dilihat kembali pengertian kecenderungan dan aliran memiliki kemiripan. Kecenderungan berarti kecondongan hati seorang mufassir dalam menafsirkan al-Qur'an. Sedangkan aliran berarti pengaruh faham mufassir terhadap penafsiran al-Qur'an. Dari sini pengertian kecenderungan dan aliran sangat dekat, sebab kecondongan hati seorang mufassir (kecenderungan) bisa menyebabkan mufassir tersebut menyertakan fahamnya dalam menafsirkan al-Qur'an (aliran).

\footnotetext{
12 Al-Zarkāshì dalam Jalāluddin al-Suyūṭ̂i, al-Itqān fì 'Ulūm al-Qur'ān, (Beirut: Dār al-Ma'rifah, t.th), 222-223.

${ }^{13}$ Abū Hayyān dalam Jalāluddin al-Suyūṭi, al-Itqān fì 'Ulūm al-Qur'ān, (Beirut:

Dār al-Ma'rifah, t.th), 222.

${ }^{14} \mathrm{http} / / /$ kbbi.web.id/cenderung.

${ }^{15} \mathrm{http}: / / \mathrm{kbbi}$.web.id/alir.
} 
Oleh sebab itu, pada pembahasan selanjutnya, penulis akan mengkrucutkan pembahasan pada beberapa aliran besar dalam sejarah Islam sekaligus penafsirannya dan karya-karya tafsirnya. Aliran besar yang penulis maksud Ahlussunnah wa al-Jama'ah, Muktazilah dan Shì'ah.

\section{Ahl al-Sunnah wa al-Jamā'ah, Muktazilah, Shī'ah dan Metode Penafsiran nya}

Pada pembahasan ini, penulis membahas tentang pengertian masing-masing aliran yang telah disebutkan di atas, latar belakang kemunculannya, tokoh-tokohnya, dan sebagian faham yang mereka anut. Sebagaimana telah penulis sebutkan di awal, bahwa aliran dalam sejarah Islam bukan hanya tiga, masih banyak lagi aliran-aliran atau faham-faham lain yang ikut mewarnai dinamika sejarah teologi Islam, seperti Khawārij, Murji'ah, Qadariyah, dan lain-lain. Pembatasan pembahasan hanya ke dalam tiga aliran ini lebih disebabkan karena minimnya pengaruh aliran-aliran lain dalam penafsiran al-Qur'an, di samping alasan lain yang tidak kalah pentingnya bagi penulis adalah minimnya sumber rujukan yang bisa diakses oleh penulis.

\section{Ahlu al-Sunnah wa al-Jamā'ah}

Kelompok ahlus sunnah wal jamaah merupakan kelompok yang menisbatkan dirinya sebagai kelompok nājiyah (selamat) yang disebut oleh Nabi dalam hadis firqah ${ }^{16}$. Abdul Qāhir al-Baghdāđì menyebutkan: Golongan ke tujuh puluh tiga adalah golongan ahl alSunnah wa al-Jamā'ah, yaitu golongan ahl ra'yu dan ahl hadith yang tidak menjual ayat-ayat Allah untuk kepentingan duniawi, para ahli fikih kedua kelompok ini, para ahli qirāahnya, para ahli hadithnya, dan para ahli kalamnya, mereka sepakat akan keesaan Allah dan sifatNya, keadilan-Nya, kebijaksanaan-Nya, nama-nama dan sifat-sifatNya, sepakat dalam hal kenabian dan imāmah, hari akhir dan beberapa ajaran inti agama.

\footnotetext{
${ }^{16}$ Hadith riwayat Abdullah bin Amru, Nabi bersabda: "Sungguh peristiwa yang menimpa Banī Isräil akan menimpa umatku, Bani Isräil terbagi menjadi tujuh puluh dua golongan, dan umatku akan terpecah menjadi tujuh puluh tiga golongan lebih satu golongan dari mereka, semuanya di neraka, kecuali satu golongan. Para sahabat bertanya, "Golongan yang mana yang akan selamat?" Nabi menjawab, "Yaitu golongan yang berpegang teguh pada sunnahku dan sunnah para sahabatku".
} 
Mereka berbeda hanya dalam halal haram masalah furu'iyah (cabang) dan tidak menyesatkan dan memfasikkan golongan lain. Mereka sepakat dalam hal keesaan Allah dan ke-qidam-anNya, keqidam-an sifat-Nya yang azali, kemungkinan melihat Allah tanpa menyamakan dengan sesuatu yang lain dan tidak menafikannya, disertai keyakinan akan kitab Allah dan Rasul-Nya, membela shariat Islam, membolehkan sesuatu yang dihalalkan al-Qur'an dan mengharamkan apa yang diharamkan al-Qur'an, menerima hadishadis yang valid dari Nabi, percaya pada hari kebangkitan dan ma'shar, percaya pada adanya pertanyaan dua Malaikat di dalam kubur, dan percaya akan adanya sorga dan mízān. ${ }^{17}$

Lebih rinci lagi, al-Baghdādi kemudian mengategorikan golongan ahl al-sunnah wa al-jamā'ah menjadi delapan kategori, yaitu:

a. Para ulama tauhid dari kelompok Mutakallimin, yang tidak menyerupakan Allah dengan sesuatu sekaligus tidak menafikan sifat-sifat Allah.

b. Para ulama fikih, baik dari golongan ahli ra'yi maupun ahli hadith, yang meyakini bahwa Allah memiliki sifat, percaya pada keqadiman-Nya, dan jauh dari keyakinan faham Qadariyah dan Muktazilah

c. Para ahli hadis yang tidak melakukan perbuatan bid'ah

d. Para ahli bahasa yang tidak berafiliasi pada golongan yang sesat

e. Para ahli qira'àt yang tidak mempercayai keyakinan para ahli bid'ah

f. Para sufi yang beribadah sesuai sunnah Nabi dan para sahabat

g. Para mujahid yang berperang di jalan Allah

h. Orang-orang yang sependapat dengan ulama ahlus sunnah wal jamaah dalam hal keyakinan. ${ }^{18}$

Dari kategorisasi seperti ini, menjadi jelas yang dimaksud dengan ahlus sunnah wal jamaah, yaitu golongan yang meyakini adanya sifat-sifat Allah dan menjalankan ajaran Islam sesuai dengan keterangan al-Qur'an, hadis Nabi dan qaūl (penjelasan) para sahabat. Konsekwensi kategorisasi ini pula mengeluarkan golongan-golongan lain, seperti Muktazilah, Jabariyah, Karāmiyah, dan beberapa golongan lainnya dari kategori ahlus sunnah wal jamaah.

${ }^{17}$ Abdul Qāhir al-Baghdādi, al-Farqu baina al-Firāq wa Bayān al-Firqah al-Nājiyah Minhum, (Kairo: Maktabah Ibnu Sinā, 1988), 39.

${ }^{18}$ Ibid. 272-274. 
Muhammad Nu'aim Muhammad Hānì Sā'i menyatakan, disebut Ahlus Sunnah wal Jamā'ah karena keyakinan mereka terhadap Sunnah Nabi Muhammad sebagai sumber syari'ah dan akidah dalam Islam dan merupakan sumber sumber kedua setelah alQur'an, kemudian disebut Jamā'ah karena banyaknya pengikut yang mengikuti madhhab dan keyakinan kelompok ini. ${ }^{19}$

Menurut Muhammad Nu'aim, Istilah Ahlus Sunnah wal Jama'ah muncul pertama kali pada akhir abad ketiga Hijriyah, yaitu ketika Imam Abu Hasan al-'Ash'ari meninggalkan majlis Muktazilah dan mendirikan aliran baru dalam bidang akidah yang disebut dengan Ahlus Sunnah yang memadukan antara akal dengan teks ketuhanan. Pada perkembangan selanjutnya nama Ahlus Sunnah dipakai oleh alAsh'ariyyah, al-Māturidiyah dan al-Hanābilah (al-Salafiyah alQadimah) sebagai tandingan terhadap kelompok Shi' ah, Muktazilah dan Khawārij. Kemudian pada akhir abad kedua puluh muncul aliran Wahabiyah yang menyebut dirinya sebagai al-Salafiyah al-Hadithah sebagai penerus dari al-Salafiyah al-Qadimah. Melalui para ulamanya yang dibesarkan oleh media dan kucuran dana besar, aliran ini menisbatkan istilah Ahlus Sunnah wal Jama'ah untuk kelompoknya. ${ }^{20}$

Menurut Yusran Asmuni, Ahlusunnah adalah penganut atau pengikut sunnah nabi Muhammad SAW, sedangkan jama'ah berarti sahabat nabi. Jadi Ahlussunnah wal Jama'ah mengandung arti penganut I'tikad/sunnah nabi dan para sahabat beliau. ${ }^{21}$

Generasi pertama Ahlussunnah adalah para sahabat Rasulullah saw., Tābi'īn dan setelah Tābi'īn (Täbi' al-Täbi'inn) yang dikenal dengan sebutan salaf, generasi selanjutnya adalah para ulama dalam aliran al-Māturidiyyah dan al-Ash'ariyyah serta para ulama fikih seperti Ahmad bin Hambal (w. 241 H.), Abu Hanifah, Mālik bin Anas (w. 178 H) Imam al-Shāfi' 'i, Imam Sufyan al-Thauri, dan yang lain. ${ }^{22}$

Dari beberapa pendapat ini bisa disimpulkan bahwa Ahlussunnah wal Jama'ah adalah orang-orang yang menjadikan al-

\footnotetext{
${ }^{19}$ Muhammad Nu'aìm Muhammad Hāni Sà'ì, al-Qānūn fì 'Aqāid al-Firaq wa alMadhāhib al-Islāmiyah, (Kairo: Dār al-Salām, 2007), 333.

${ }^{20}$ Ibid. 19.

${ }^{21}$ M Yusran Asmuni, Ilmu Tauhid, (Jakarta: PT Raja Grafindo Persada, 1996), 104.

22 Abdul Rozak dan Rosihon Anwar, Ilmu Kalam, (Bandung: CV Pustaka Setia, 2009), Cet. IV, 119.
} 
Qur'an, Sunnah Nabi Muhammad, Ijmāà' dan Qiyās sebagai pijakan dalam berkeyakinan, beribadah dan beramal.

Landasan keyakinan Ahlussunnah wal Jama'ah dalam hal keimanan adalah keyakinan dalam hati, mengucapkan dengan lisan dan membuktikan dengan perbuatan. Ahlusunnah menetapkan bahwa seseorang dikatakan beriman apabila meyakini Allah sebagai Tuhannya, beriman kepada malaikat-malaikat-Nya, beriman kepada kitab-kitab Allah, beriman kepada Nabi dan Rasul Allah, beriman kepada hari akhir (kiamat) dan beriman kepada qaḍa', dan qadar yang ditetapkan Allah.

Menurut Ahlussunnah, seseorang belum dikatakan muslim apabila tidak menjalankan hukum Islam yang lima yaitu: membaca syahadat, shalat, puasa, zakat dan haji. Ahlussunnah juga meyakini bahwa al-Qur'an sebagai kalam Allah bukan makhluk seperti yang diyakini muktazilah. Ahlussunnah juga menetapkan sumber keyakinan (i'tiqād) dalam Islam adalah wahyu. ${ }^{23}$

Para tokoh ahli tafsir dari golongan Ahlu al-Sunnah wa alJamā'ah dan karyanya, di antaranya adalah, Jāmi' al-bayān fí Tafsìr al-Qur'ān karya Imam al-Ṭabari, Bahr al-'Ulūm karya al-Samarqandi, al-Kashf wa al-Bayān 'an Tafsìr al-Qur'ān karya al-Tha'labī, Ma'ālim al-Tanzīl karya al-Baghāwì, al-Muharrār al-Wajīz fí Tafsìr al-Kitāb al-'Azīz karya Ibnu 'Ațiyah, Tafsìr al-Qur'ān al-'Azīm karya Ibnu Kathìr, al-Jawāhir al-Hisān fí Tafsìr al-Qur'ān karya al-Tha'ālabì, alDur al-Manthür fí Tafsìr bi al-Ma'thür karya al-Suyūți. Karya-karya tafsir ini menggunakan sumber tafsir bi al-ma'thür.

Sementara tokoh tafsir golongan ahlu al-Sunnah wa alJamā'ah yang menggunakan sumber ra'yu di antaranya adalah kitab Mafătị al-Ghaīb karya Fakhr al-Rāzì, Anwā' al-Tanzīl wa Asrār alTa'wìl karya al-Baiḍ̄āìi, Madārik al-Tanzīl wa Haqāiq al-Ta'wìl karya al-Nasafì, Lubāb al-Ta'wìl fì Ma'ān al-Ta'wīl karya al-Khāzin, al-Baḥr al-Muhịt karya Abu Ḥayyān, Gharāib al-Qur'ān wa Raghāib al-Furqān karya al-Naisābūri, Tafsìr al-Jalālaīn karya al-Mạ̣alli dan al-Suyūtị, al-Sirāj al-Munìr karya al-Khatịib al-Sharbinì, Irshäd al'Aql al-Salìm ilā Mazāyā al-Kitāb al-Karìm karya Abu Su'ùd, Rüh alMa'ānì karya al-Alūsì. Al-Dhahabì kemudian mengatakan, "Kami telah menyebutkan beberapa nama kitab penting yang menggunakan

\footnotetext{
${ }^{23}$ Muhammad Nu'aìm Muhammad Hāni Sā'ì, al-Qānūn fì 'Aqāid al-Firaq wa alMadhāhib al-Islāmiyah, (Kairo: Dār al-Salām, 2007), 333.
} 
sumber al-ra'yu al-Jāiz , karya-karya tafsir itu merupakan tafsir ahl al-Sunnah wa al-Jamā'ah ". ${ }^{24}$

Metode yang digunakan oleh Ahlussunnah wa al-Jama'ah dalam tafsir bi al-ma'th $\bar{u}$ adalah menafsirkan ayat-ayat al-Qur'an dengan ayat yang lain, menafsirkan al-Qur'an dengan riwayat dari Nabi Muhammad, menafsirkan al-Qur'an dengan riwayat dari para sahabat, dan menafsirkan al-Qur'an dengan riwayat dari tābi'īn (generasi setelah sahabat).

Sedangkan metode mereka dalam tafsir bi al-ra'yi adalah mengambil dasar penafsirannya dari al-Qur'an, dari hadis Nabi, dari pendapat para sahabat yang valid, dari kemutlakan bahasa Arab, dan dari makna ayat yang sesuai dengan siyagh kalam-nya dan sesuai dengan pandangan umum shari' ah.

\section{Muktazilah}

Menurut al-Baghdādi, golongan Muktazilah muncul pada masa Hasan al-Bașrīi, yaitu ketika Wāsil bin Ațā' yang didukung oleh Amru bin 'Ubaìd berbeda pendapat dengan Hasan al-Bașri mengenai qadar dan al-manzilah baina al-manzilatain, kemudian Hasan al-Bașrī mengusir keduanya dari majlisnya, sehingga mereka berdua mengambil tempat di salah satu pojok masjid di Basrah, lalu mereka dan para pengikutnya mendapat sebutan muktazilah karena telah memisahkan diri dari kesepakatan umat dengan mengatakan bahwa orang Islam yang fasik tidak termasuk orang mukmin dan juga tidak termasuk orang kafir. ${ }^{25}$

Keyakinan utama kaum Muktazilah adalah bahwa al-Qur'an makhluk, manusia tidak mungkin bisa melihat Allah di akhirat nanti, orang Islam yang melakukan dosa besar akan berada di al-manzilah bain al-manzilatain, dan lain sebagainya.

Golongan Muktazilah memiliki lima prinsip dasar yang mereka sebut dengan al-uṣūl al-khamsah, kelima dasar tersebut meliputi, al-tauhid, al-adl, al-wa'd wa al-wa'id, al-manzilah baina almanzilatain, al-amru bi al-ma'rüf wa al-nahyu 'an al-munkar. Kelima prinsip dasar ini harus dimiliki oleh orang yang mengaku Muktazilah, bahkan salah seorang pemimpin Muktazilah yang bernama, Abu alHasan al-Khayyāt sampai mengatakan, "Seseorang tidak berhak

\footnotetext{
${ }^{24}$ Al-Zahabī, al-Tafsìr wa al-Mufassirūn, (Kairo: Dār al-Hadith, 2005), 312.

${ }^{25}$ Abdul Qāhir al-Baghdāđi, al-Farqu baina al-Firāq wa Bayān al-Firqah al-Nājiyah Minhum, (Kairo: Maktabah Ibnu Sinā, 1988), 35.
} 
mengaku Muktazilah kecuali dia yang memenuhi (memiliki) al-uṣūl al-khamsah: al-tauhid, al-adl, al-wa'd wa al-wa'ìd, al-manzilah baina al-manzilatain, al-amru bi al-ma'rüf wa al-nahyu 'an al-munkar, jika kelima prinsip dasar ini sudah terpenuhi maka ia pantas disebut Muktazilah."26

Kelima dasar inilah yang kemudian mempengaruhi pendapatpendapat Muktazilah, bahkan para mufassirnya sampai berani menakwilkan makna suatu ayat dari makna lahir ke makna yang lain, demi menyesuaikannya dengan prinsip dasar mereka. Hal ini mereka lakukan demi mencari legitimasi pendapat mereka dari sumber utama ajaran Islam, yaitu al-Qur'an. Lebih detil, akan penulis sertakan contoh penafsiran mereka di pembahasan berikutnya.

Metode yang dilakukan oleh Muktazilah dalam menafsirkan al-Qur' an di antaranya adalah:

a. Menafsirkan al-Qur'an berlandaskan pada prinsip dasar aliran atau madhhab mereka (Muktazilah) yang lima, dan tidak diragukan lagi bahwa penafsiran yang ingin dijadikan legitimasi terhadap suatu keyakinan tertentu memerlukan kemahiran ekstra, dan cara seperti ini lebih sering menggunakan akal daripada naql demi menyelaraskan apa yang ditafsirkannya dengan landasan alirannya atau untuk menolak yang tidak sesuai dengan alirannya

b. Menolak hadis sahih (valid) yang bertentangan dengan landasan atau perinsip dasar aliran mereka, namun hal ini tidak dilakukan oleh semua kaum intelektual Muktazilah

c. Pengakuan bahwa semua penafsiran yang dihasilkan oleh kaum Muktazilah merupakan maksud Allah dalam ayat-ayat tersebut. Dampak dari perinsip seperti ini adalah penafian terhadap tafsir lain yang berbeda dengan penafsiran mereka

d. Penafsiran dengan berlandaskan pada bahasa merupakan hal penting bagi kaum Muktazilah, bahkan bahasa menduduki peringkat pertama dalam menafsirkan al-Qur'an

e. Mengalihkan qirā'ah mutawătirah yang bertentangan dengan pendapat madhhab mereka, seperti dalam menafsirkan ayat 164 dari Surat al-Nisā'

$$
\text { وَكَلَّمَ اللهُ مُوْسَسى نَكْلِيْماً }
$$

Semestinya masdar yang ada dalam kalimat tersebut sebagai ta'kīd (penguat) bagi fi'il agar tidak dipahami secara majāzi (metafora). Namun kaum Muktazilah merubah bacaan teks ini dengan

${ }^{26}$ Muhammad Abū Zahrah, Tärīkh al-Jadal, (Kairo: al-'Ulūm, 1934), 208. 
bacaan yang maknanya sesuai dengan pendapat mereka, mereka membaca ayat tersebut dengan,

$$
\text { وَكَلَّمَ اللهَ مُوْسَى نَكْلِيْماً }
$$

Dengan me-nashab-kan lafaz Allah dengan menjadikannya sebagai maf'ūl dan me-rafa'-kan bacaan Mūsā sebagai fä'ìl. Ada juga penafsir Muktazilah lain yang membaca kalimat tersebut sesuai dengan qirā'ah mutawătirah tapi menafsirkannya dengan penafsiran yang sangat jauh sehingga ayat tersebut tidak bertentangan dengan madhhab mereka, dan mengatakan bahwa kallama dari al-kalmu yang berarti al-jarhu (luka), jadi maknanya, "Allah melukai Musa dengan kuku-kuku cobaan dan cakar-cakar fitnah."

Penafsiran seperti ini terdapat dalam tafsir al-Kashshāf yang dalam kitab tersebut Zamakhshari menyebutkan riwayat dari Ibrāhīm dan Yahyā bin Withāb bahwa keduanya membaca kallamallhu dengan nashab, kemudian Zamakhshari juga menyebutkan, dan di antara penafsiran yang baru adalah mengartikan kallama dengan al-kalmu, dan maknanya adalah "Allah melukai Musa dengan kuku-kuku cobaan dan cakar-cakar fitnah." 28

Tokoh-tokoh Muktazilah yang oleh al-Suyuṭi dan al-Dāwūdi disinyalir memiliki karya tafsir adalah, Abu Bakar Abdurrahmān bin Kisān (w. 240 H.) tapi informasi mengenai karya tafsirnya tidak sampai kepada kita, Muhammad bin Abdul Wahab bin Salām Abū 'A $\bar{i}$ al-Jubbai (w. 303 H.) tapi informasi mengenai karya tafsirnya tidak sampai kepada kita, al-Ka'bi al-Mu'tazili (w. 319 H.), menurut pengarang Kashf al-Zunūn dia memiliki tafsir yang cukup besar sampai dua belas jilid, tapi informasi mengenai karya tafsirnya juga tidak sampai kepada kita, Abū Hāshim Abdu al-Salām bin Abì Alì alJubbai (w. 321 H.), informasi mengenai karya tafsirnya juga tidak sampai kepada kita, Abu Muslim Muhammad bin Baḥr al-Aṣfahānī (w. 322 H.) nama kitabnya Jämi' al-Ta'wil li Muhkam al-Tanzîl, terdiri dari empat belas jilid dan ada yang menyebutnya berjumlah dua puluh jilid, kitab ini sampai kepada kita.

Abu al-Hasan Ali bin 'Isā al-Rummānì (w. 384 H.), namun kitab ini tidak sampai kepada kita, Ubaidillah bin Muhammad al'Arūdi al-Mu'tazili (w. 387 H.), kitab ini juga tidak sampai kepada kita, al-Qāọi Abd al-Jabbār bin Ahmad al-Hamdāni (w. 415 H.) memiliki karya Tanzīh al-Qur'ān 'an al-Mată'in, kitab ini sampai

${ }^{27}$ Al-Ẓahabì, al-Tafsìr wa al-Mufassirūn, (Kairo: Dār al-Hadith, 2005), 320.

${ }^{28}$ Zamakhshari, al-Kashshāf, (Kairo, Maktabah Misr, t.th.), Juz 1, Hal. 512. 
kepada kita. al-Sharif al-Murtaḍā (w. 436 H.) karya tafsirnya terdapat dalam kitabnya Ghurar al-Fawāid wa Durar al-Qalāid. Abdu al-Salām bin Muhammad bin Yūsuf al-Qazwainī (w. 483 H.), kitab ini tidak sampai kepada kita. Abū al-Qāsim Mahmūd bin Umar al-Zamakhsari (w. 538 H.) memiliki karya tafsir al-Kashshäf.

Dari sekian banyak mufassir Muktazilah, hanya tiga karya tafsir yang sampai kepada kita, yaitu: Tanzīh al-Qur'ān 'an alMatā'in karya al-Qāọ̣i Abd al-Jabbār bin Ahmad al-Hamdānì (w. 415 H.), Amāli karya al-Sharīf al-Murtaḍā, dan al-Kashshāf karya alZamakhshari. $^{29}$

Metode yang digunakan Muktazilah dalam menafsirkan ayatayat al-Qur'an adalah...

kaum Mu'tazilah telah menegakkan prinsip mereka yang lima, yaitu: tauhid, keadilan Ilahi, al-wa'd wal-wa'id, al-manzilah baynal manzilatayn, dan amar ma'ruf nahyi munkar. Mereka meletakkan kaidah-kaidah tersebut terlebih dahulu, kemudian di atasnya mereka membangun madzhab i'tizal mereka itu, kemudian setelah itu mereka berusaha untuk menundukkan ayat-ayat al-Qur'an, dan merumuskan daripadanya dalil-dalil yang menguatkan kelima prinsip mereka itu. Metode yang mereka tempuh ini jelas bertentangan dengan metode madzhab Ahlus Sunnah wal-Jamaah. Mereka berusaha sekuat tenaga mendayagunakan akal pikiran mereka untuk menyelaraskan al-Qur'an dengan dasar-dasar pemikiran madzhab mereka. Sedangkan para ulama Ahlus Sunnah wal-Jamaah dalam penafsirannya hanya mencakupkan diri dengan kutipan-kutipan dan para sahabat dan tabi'in. Mereka hanya menggunakan ijtihad dalam perkara-perkara yang tidak ada nash mengenainya, tanpa mengikuti dorongan hawa nafsu ataupun peng-ada-adaan.

\section{Shi'ah}

Shi' ah secara bahasa adalah sahabat dan pengikut, sementara dalam tradisi ahli fikih dan para mutakallimin baik klasik maupun modern, kata Shi'ah mengacu pada pengikut Ali dan keturunannya. Para penganut Shi' ah ini sepakat bahwa al-imāmah (kepemimpinan) bukan mașälih al-ämmah yang bisa dikonsumsi oleh masyarakat umum, tapi merupakan penunjukan oleh pemimpin sebelumnya. Hal ini termasuk rukun Islam yang tidak boleh dibiarkan begitu saja oleh

${ }^{29}$ Al-Zahabī, al-Tafsìr wa al-Mufassirūn, (Kairo: Dār al-Hadith, 2005), 328-331. 
seorang Nabi, dan tidak boleh diserahkan kepada masyarakat umum. $^{30}$

Sedangkan menurut Rosihon Anwar Shī'ah, secara bahasa, adalah pengikut, pendukung, partai, atau kelompok, dan secara istilah adalah kaum muslim yang dalam bidang spiritual dan keagamaan merujuk pada keturunan Nabi Muhammad saw. atau yang disebut sebagai ahl al-bait. Dalam bahasa mudahnya, dan hal ini lazim dikenal di dunia Islam, Shì' ah adalah aliran dalam teologi Islam yang memihak dan sangat memuliakan Ali beserta keluarganya. ${ }^{31}$

Menurut al-Dhahabì, Shi' ah merupakan madhhab paling awal dalam sejarah Islam, yaitu muncul pada akhir pemerintahan Usmān bin Affan (bahkan ada yang mensinyalir madhhab ini muncul ketika pemilihan khalifah pertama kali setelah Nabi Muhammad wafat), kemudian tumbuh dan berkembang pada masa kekhalifahan 'Ali bin Abì Țālib, yaitu ketika ia berinteraksi dengan masyarakat mereka merasa kagum dan takjub akan agama, ilmu, dan kewibawaannya, sehingga muncul dari mereka orang-orang yang mengagungagungkannya dan menyebarkannya kepada masyarakat. Setelah itu datang masa Bani Umayyah yang mengejar-ngejar dan menzalimi anak keturunan Ali sehingga mayoritas umat Islam merasa iba dan kasihan terhadap mereka. Sejak saat itu Shỉ'ah menjadi madhhab yang memiliki banyak pengikut. ${ }^{32}$

Shi' ah sendiri terbagi ke dalam beberapa kelompok, yang dalam makalah ini penulis hanya membahas tentang Shi' ah Imāmiyah al-Ithnā 'Ashariyah, yaitu kelompok sempalan dari Shì' ah Imāmiyah. Mereka berpendapat bahwa Nabi Muhammad menunjuk Ali bin Abi Ṭālib sebagai penggantinya secara langsung dengan naș yang zāhir dan tidak melalui bukan dengan bahasa yang tersirat melalui ciri-ciri yang disebutkan Nabi. Mereka juga berpendapat bahwa imāmah setelah Ali hanya terbatas pada keturunan Ali dari Fạtimah, yaitu: Hasan bin Ali (atas wasiat Ali), dilanjutkan oleh Husain bin Ali,

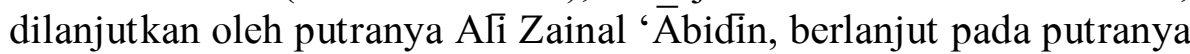
Muhammad al-Bāqir, pindah pada anaknya Jakfar al-Ṣādiq, , dilanjutkan oleh Mūsā al-Kāẓim, pada anaknya Ađi Riḍā, dilanjutkan anaknya Muhammad al-Jawwād, dilanjutkan anaknya 'Ali al-Hādi,

\footnotetext{
${ }^{30}$ Abdurrahman bin Muhammad bin Khaldūn, Muqaddimah Ibnu Khaldūn (Kairo: al-Taufiqiyah, t.th.), Hal. 218.

${ }^{31}$ Rosihon Anwar, Samudera al-Qur'an (Bandung: CV. Pustaka Setia, 2001), 222.

${ }^{32}$ Al-Zahabī, al-Tafsīir wa al-Mufassirūn, (Kairo: Dār al-Hadith, 2005), II. 2.
} 
dilanjutkan anakna al-Hasan al-'Askari, dilanjutkan anaknya alMahdi al-Muntazar, yaitu imam yang kedua belas, yang akan kembali di akhir masa. ${ }^{33}$

Ajaran Shī' ah al-Imāmiyah al-Ithnā 'Ashariyah yang terkenal adalah al-'iṣmah, al-mahdiyah, al-raj'ah, al-taqiyah. Al-'ịmah yaitu ajaran yang meyakini bahwa para imam harus ma'sūm dari dosa-dosa kecil dan dosa-dosa besar sepanjang hidupnya, mereka tidak boleh salah dan tidak boleh lupa. Sedangkan al-mahdiyah maksudnya adalah al-imām al-muntazar (pemimpin yang ditunggu). Al-raj'ah maksudnya adalah bahwa setelah munculnya al-mahdi al-muntazar Nabi Muhammad, Ali bin Abi Ṭālib, Hasan, Husain, dan para imam akan hidup kembali, bahkan musuh-musuh mereka pun (menurut anggapan orang-orang Shï'ah) seperti Abu Bakar dan Umar juga akan hidup kembali hingga para imam bisa menghukum mereka, setelah itu mereka akan mati semua dan hidup kembali di hari kiamat. Sementara al-taqiyah maksudnya adalah berbohong agar ajarannya tidak diketahui orang lain, mereka boleh berpura-pura taat kepada pemimpin yang ada, tetapi hati mereka tetap yakin terhadap imam yang tersembunyi. ${ }^{34}$

Tokoh-tokoh Shì'ah al-Imāmiyah al-Ithnā 'Ashariyah yang memiliki karya tafsir adalah, Tafsir Hasan al-'Askar̄i (w. 254 H.) kitab ini sampai kepada kita. Tafsir Muhammad bin Mas'ūd al'Iyāshi, tapi kitab ini tidak sampai ke tangan kita. Tafsìr Ali bin Ibrahim al-Qummīi, kitab ini sampai ke tangan kita. Al-Tibyān karya Abū Jakfar al-Ṭ̂̄isi, tafsir ini juga tidak sampai ke tangan kita. Majma' al-Bayā̄n karya Abū ATi al-Ṭibrisì, kitab ini terdapat di Dār al-Kutub al-Mișriyah dan Maktabah Azhariyah. Al-Säfi karya Mullāa Hasan al-Kāshānì, kitab ini ada di Dār al-Kutub al-Mișriyah. Al-Asfā karya Mullā Hasan al-Kāshāni, kitab ini merupakan ringkasan dari kitab al-Săfi, dan kitab ini ada di Dār al-Kutub al-Mișriyah dan Jāmi'ah al-Qāhirah. Al-Burhān karya Hāshim bin Sulaimān alBaḥrāni (w. 1107 H.), kitab ini ada sampai sekarang di Dār al-Kutub al-Miṣriyah. Mir'āt al-Anwār wa Miskāt al-Asrār karya Maulā Abdul Latîf al-Kāzarāni, kitab ini hanya muqaddimahnya saja yang sampai kepada kita. al-Muallaf karya Nüruddin, kitab ini sampai kepada kita dan ada di Dār al-Kutub al-Mișriyah. Tafsìr al-Qur'ān al-Karim karya Maulā Sayyid Abdullah bin Muhammad bin Riḍā al-'Alawī, kitab ini

\footnotetext{
${ }^{33}$ Ibid. II. 8.

${ }^{34}$ Ibid. II. 9.
} 
ada di Dār al-Kutub al-Mișriyah. Bayān al-Sa'ādah fi Maqāmāt al'Ibādah karya Sulțān bin Muhammad bin Haidar al-Kharāsāni dan masih ada sampai sekarang di Dār al-Kutub al-Mișriyah. $\bar{A} \bar{l} \bar{a}$ ' alRahmān fì Tafsìr al-Qur'ān karya Muhammad Jawwād bin Hasan alNajafî, kitab ini ada di Dār al-Kutub al-Miṣriyah, tapi hanya juz satu saja. $^{35}$

Bagi kalangan Shi' ah, al-Qur'an memiliki dua aspek, yaitu aspek lahir dan aspek batin, dan aspek batin menurut mereka lebih kaya daripada aspek lahir. Rosihon Anwar menyatakan, secara umum, corak tafsir Shi' ah adalah tafsir simbolik (menekankan pada aspek batin al-Qur'an). ${ }^{36}$

Sementara metode tafsir yang digunakan oleh para mufassir Shī'ah al-Imāmiyah al-Ithnā 'Ashariyah adalah metode takwil. Hal ini mereka lakukan untuk menyesuaikan ayat-ayat Allah dengan prinsip-prinsip ajaran mereka. Misalnya dengan prinsip imamah, sehingga, mereka akan berusaha menjadikan al-Qur'an sebagai dalil (justifikasi) bagi klaim-klaim mereka. ${ }^{37}$ Dan takwil sebagaimana dijelaskan Jalaluddin al-Suyūtị adalah memindahkan makna ayat dari makna yang dikehendaki oleh ayat tersebut. ${ }^{38}$ Atau lebih jelas, seperti yang dinyatakan Rosihon Anwar, takwil adalah mengartikan lafaz dengan beberapa alternatif kandungan makna yang bukan makna lahirnya. ${ }^{39}$

Di samping metode ini, Shì'ah al-Imāmiyah al-Ithnā 'Ashariyah juga punya anggapan bahwa al-Qur'an memiliki makna lahir dan makna batin bahkan makna batin lebih banyak daripada makna lahir, dan pengetahuan tentang kedua makna tersebut ada pada para imam. Anggapan lain kaum Shì'ah al-Imāmiyah al-Ithnā 'Ashariyah adalah bahwa al-Qur'an banyak mengulas tentang para imam, para wali, dan musuh-musuh mereka. Di samping itu, mereka juga beranggapan bahwa al-Qur'an telah dirubah dan diganti dari alQur' an yang ada pada masa Nabi. ${ }^{40}$

\footnotetext{
${ }^{35}$ Ibid. II. 34-35.

${ }^{36}$ Rosihon Anwar, Samudera al-Qur'an (Bandung: CV. Pustaka Setia, 2001), 218.

${ }^{37}$ Mahmūd Basūni Faudah, Tafsir-tafsir al-Qur'an: Perkenalan dengan Metodologi Tafsir, terj. M. Mochtar Zoerni dan Abdul Qodir Hamid (Bandung: Pustaka, 1987), 135-136.

${ }^{38}$ Jalaluddin al-Suyūtị, al-Itqan fì 'Ulūm al-Qur'ān, (Beirut: Dār al-Fikr, 1951), II, 173.

${ }^{39}$ Rosihon Anwar, Samudera al-Qur'an (Bandung: CV. Pustaka Setia, 2001), 242.

${ }^{40}$ Al-Zahabì, al-Tafsìr wa al-Mufassirūn, (Kairo: Dār al-Hadith, 2005), II. 23.
} 


\section{Standar Penafsiran Menurut Ulama 'Ulūm al-Qur'an}

Ulama 'ulūm al-Qur'an memberikan standar atau baro-meter cara penafsiran yang harus diterapkan oleh seorang mufassir ketika menafsirkan al-Qur'an agar penafsirannya sesuai dengan kaidahkaidah yang ada dalam 'ulūm al-Qur'an.

Untuk tafsir bi al-ma'thür adalah menafsirkan ayat-ayat alQur'an dengan ayat al-Qur'an yang lain jika ada, menafsirkan alQur'an dengan riwayat yang marfu' dan șaḥih dari Nabi Muhammad, menafsirkan al-Qur'an dengan riwayat yang valid dari para sahabat, menafsirkan al-Qur'an dengan riwayat yang valid dari tābi'in (generasi setelah sahabat), dan menjadikan pendapat ulama salaf sebagai pertimbangan dalam menafsirkan ayat al-Qur'an.

Cara seperti ini tidak disebutkan secara langsung oleh para ulama 'ulūm al-Qur'an sebagai standar baku dalam menafsirkan secara bi al-ma'thür, hal ini penulis simpulkan sendiri dengan mengacu pada cara penafsiran yang ada dalam tafsir-tafsir yang menggunakan sumber bi al-ma'thür seperti tafsir al-Qur'an al-'Azim karya Ibnu Kathīr dan Jāmi' al-Bayān karya al-Ṭabari.

Apa yang dilakukan para ulama 'ulūm al-Qur'an yang tidak memberikan standar baku terhadap penafsiran bi al-ma'thür ini bisa dimaklumi mengingat tafsir dengan menggunakan sumber bi alma'thür memiliki sumber yang jelas dalam menafsirkan ayat-ayat alQur'an, dan dengan alasan yang sama menjadikan para ahli tafsir dengan cara ini memiliki kemungkinan yang sangat kecil kalau tidak bisa dibilang tidak ada sama sekali kemungkinan untuk menyelewengkan maknanya.

Sementara untuk tafsir yang menggunakan sumber bi al-ra'yi, para ulama 'ulūm al-Qur'an memberikan beberapa syarat agar tafsirnya bisa diterima. Di antara syarat tersebut sebagai yang disebutkan oleh Mannā' al-Qațān, al-Qațān menyatakan, para ulama telah menyebutkan syarat-syarat yang harus dimiliki setiap mufassir yang dapat kami ringkaskan sebagai berikut: ${ }^{41}$

1. Akidah yang benar, sebab akidah sangat berpengaruh terhadap jiwa pemiliknya dan seringkali mendorongnya untuk mengubah naș-nas dan berkhianat dalam penyampaian berita

\footnotetext{
${ }^{41}$ Mannā' Khalil al-Qatṭān, Studi Ilmu-ilmu Qur'an, terj. Mudhakir AS. (Jakarta: Litera Antarnusa, 2001), 462-465.
} 
2. Bersih dari hawa nafsu, sebab hawa nafsu akan mendorong pemiliknya untuk membela kepentingan madzhabnya sehingga ia menipu manusia dengan kata-kata halus dan keterangan menarik

3. Menafsirkan lebih dahulu al-Qur'an dengan al-Qur'an, karena sesuatu yang masih global pada satu tempat telah terperinci di tempat lain dan sesuatu yang dikemukakan secara ringkas di suatu tempat telah diuraikan di tempat lain

4. Mencari penafsiran dari sunnah, karena sunnah berfungsi sebagai pensyarah al-Qur'an dan penjelasnya. Al-Qur'an telah menyebutkan bahwa semua hukum (ketetapan) Rasulullah berasal dari Allah

5. Apabila tidak didapatkan penafsiran dari sunnah, hendaklah meninjau pendapat para sahabat karena mereka lebih mengetahui tentang tafsir al-Quran; mengingat merekalah yang menyaksikan qarinah (konteks) dan kondisi ketika al-Qur'an diturunkan di samping mereka mempunyai pemahaman (penalaran) sempurna, ilmu yang sahihh, dan amal yang saleh

6. Apabila tidak ditemukan juga penafsiran dalam al-Qur'an, sunnah maupun dalam pendapat para sahabat maka sebagian besar ulama, dalam hal ini, memeriksa pendapat täbi'inn (generasi setelah sahabat)

7. Pengetahuan bahasa Arab dengan segala cabangnya, karena alQur'an diturunkan dalam bahasa Arab dan pemahaman tentangnya amat tergantung pada penguraian mufradāt (kosa kata) lafaz-lafaz dan pengertian-pengertian yang ditunjukkannya menurut letak kata-kata dalam rangkaian kalimat

8. Pengetahuan tentang pokok-pokok ilmu yang berkaitan dengan al-Qur'an, seperti ilmu qirāah, ilmu tauhid, dan ilmu ușūl al-tafsir

9. Pemahaman yang cermat sehingga mufassir dapat mengukuhkan sesuatu makna atas yang lain atau menyimpulkan makna yang sejalan dengan naṣ-naș syariah.

Imam al-Suyưtîi memberikan syarat ilmu yang harus dikuasai oleh mufassir yang ingin menafsirkan al-Qur'an bi al-ra'yi, karena berbagai ilmu tersebut merupakan alat untuk memahami al-Qur'an, syarat-syarat itu meliputi: Ilmu al-lughah, ilmu al-nahw, ilmu sarf, ishtiqāq, ilmu ma'āni, ilmu al-bayān, ilmu al-badì', ilmu uṣūl al-dìn, ilmu uṣūl al-fiqh, ilmu asbāb al-nuzūl, ilmu qașas, ilmu al-nāsikh wa 
al-mansūkh, hadis-hadis yang menjelaskan ayat-ayat yang mujmal dan mubham, dan ilmu al-mauhibah. ${ }^{42}$

Lebih lanjut al-Suyūtîi memberikan beberapa hal yang harus dihindari oleh seorang mufassir, agar tidak terjebak pada penafsiran dengan al-ra'yu al-fäsid, di antaranya:

1. Mengira-ngira penjelasan maksud Allah dalam al-Qur'an tanpa memperhatikan tata bahasa dan landasan syariah

2. Membahas secara mendalam hal-hal yang tidak dijelaskan secara rinci oleh Allah, seperti ayat-ayat mutashäbihāt, hal-hal ghaib yang tidak ada penjelasannya secara naqIi

3. Menafsirkan al-Qur'an dengan hawa nafsu dan hanya pertimbangan istihsān

4. Menafsiri al-Qur'an dengan mengacu pada madhhab al-fāsid, yaitu dengan menjadikan madhhab sebagai patokan utama, dan tafsir sebagai legitimasi terhadap pendapat madhhab tersebut

5. Menafsirkan al-Qur'an dengan memastikan bahwa maksud Allah adalah seperti ini dan seperti ini tanpa berlandaskan pada dalil. ${ }^{43}$

Para ulama juga telah menjelaskan metode yang harus ditempuh oleh seorang mufassir dalam menafsirkan al-Qur'an, metode tersebut adalah:

1. Menyesuaikan tafsir dengan ayat yang ditafsirkan, tidak boleh kurang dari yang semestinya dijelaskan dan tidak boleh menambahkan dengan sesuatu yang tidak sesuai dengan makna ayat

2. Berhati-hati dalam menentukan makna haqiqqi dan makna majäzi, agar tidak salah menetapkan, yang haqiq $\bar{i}$ dianggap majāzi, begitu pula sebaliknya

3. Berhati-hati dalam hal susunan, maksud, dan kesesuaian mufradāt dalam memahami makna kalimat

4. Berhati-hati dalam tanāsub al-āyāt (kesesuaian antar-ayat), harus menjelaskan letak kesesuaiannya dan unsur keterkaitan antara ayat sebelum dan sesudahnya

5. Menyertakan asbāb al-nuzūl

6. Menjelaskan tentang mufradāt (kosa kata) dari segi bahasa, sharf, ishtiqāq, kemudian menjelaskan tentang susunan kalimatnya,

\footnotetext{
42 Jalaluddin al-Suyūṭi, al-Itqan fí 'Ulūm al-Qur'ān, (Beirut: Dār al-Fikr, 1951), II, 231-232.

${ }^{43}$ Ibnu Naqīb dalam Jalaluddin al-Suyūțì, al-Itqan fí 'Ulūm al-Qur'ān, (Beirut: Dār al-Fikr, 1951), II, 234.
} 
dimulai dari i'rāb, penjelasan makna, al-bayān, al-badi', makna yang dimaksud dalam ayat, dan menentukan hukum yang bisa diambil dari ayat tersebut sesuai kaidah-kaidah syariat

7. Sebisa mungkin seorang mufassir menjauhi anggapan adanya pengulangan dalam al-Qur'an, karena perbedaan susunan pada ayat yang sama bisa mengandung arti berbeda

8. Seorang mufassir harus sadar, harus pandai dan harus tahu tentang aturan dalam tarjīh, sehingga ketika ada satu ayat yang mengandung beberapa kemungkinan makna, maka dia bisa memilih yang paling räjih. ${ }^{44}$

Dengan menyebut beberapa hal yang berkaitan dengan syarat dan metode tafsir seperti ini akan memudahkan seseorang ketika ingin menilai suatu tafsir, apakah suatu karya tafsir sesuai dengan syarat dan metode yang disodorkan oleh para pakar di bidang 'ulūm al-Qur' an atau belum.

Pada pembahasan selanjutnya akan dimuat contoh penafsiran dari masing-masing aliran, tentunya tidak semua karya tafsir dari masing-masing aliran tersebut bisa disebutkan di sini, penulis hanya mencukupkan mengambil satu sampel karya tafsir yang penulis anggap bisa mewakili masing-masing aliran. Kemudian memberikan analisa terhadap contoh penafsiran tersebut sesuai dengan standar penafsiran ulama 'ulūm al-Qur'an.

\section{Penafsiran Ahlussunnah wa al-Jama'ah, Muktazilah dan Shī'ah 1) Ahlussunnah wa al-Jamā'ah}

Penulis mengambil sampel penafsiran yang mewakili aliran Ahlussunnah wa al-Jamaah dari kitab al-Ṭabari ketika menafsirkan ayat yang memiliki kaitan dengan pendapat Ahlussunnah wa alJamā'ah tentang kemungkinan makhluk (manusia) bisa melihat alkhālik (Allah) di akhirat nanti.

Al-Ṭabari menafsirkan ayat 23 dari Surat al-Qiyāmah dengan menyebutkan:

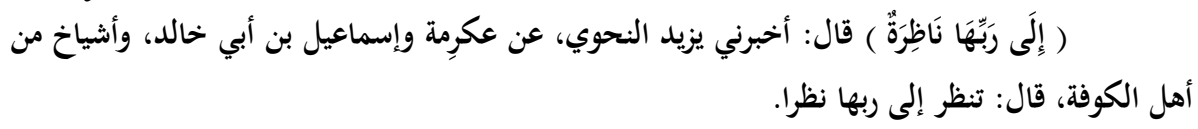

${ }^{44}$ Jalaluddin al-Suyūṭì, al-Itqan fì 'Ulūm al-Qur'ān, (Beirut: Dār al-Fikr, 1951), II, 237-238. Dan Abdul Aẓim al-Zarqānī dalam Manāhil al- 'Irfān, (Kairo: Maṭba'ah Shubrā, 1359 H.), I, 445-446. 


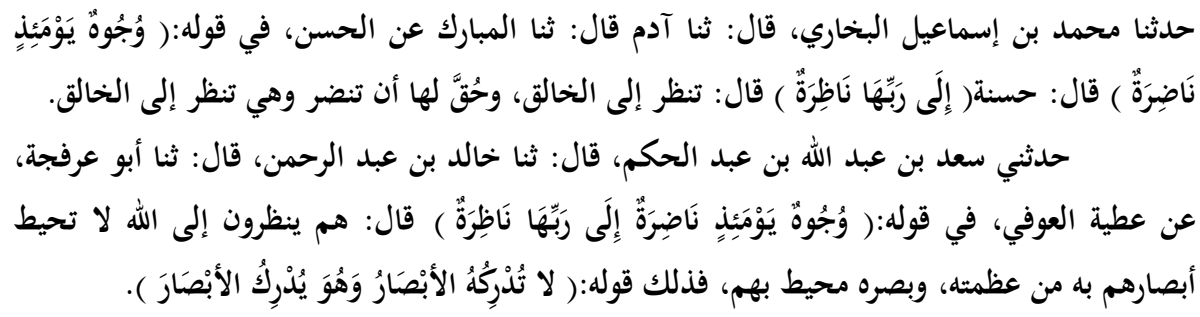

Setelah menyebutkan pendapat beberapa ulama, kemudian alTabari menyatakan bahwa para penduduk sorga akan melihat Allah di akhirat nanti. ${ }^{45}$

Penafsiran ini dihasilkan oleh al-Tabari dengan mengacu pada makna haqīiqi kata nāzirah, jadi sebelum melangkah pada makna majäzi yang merupakan langkah alternatif jika langkah pemaknaan secara haqiq $\bar{i}$ tidak memungkinkan al-Ṭabari terlebih dahulu mencari kemungkinan pemaknaan secara haqiq $\dot{i}$, dan ternyata pemaknaan ini kemudian mendapat penguatan dari hadis Nabi yang diriwayatkan oleh al-Bukhari dalam kitab shahihnya: ${ }^{46}$

حدثنا عمرو بن عون حدثنا خالد أو هشيم عن إسماعيل عن قيس عن جرير قال : كنا جلوسا عند النبي

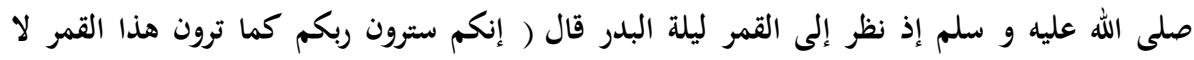

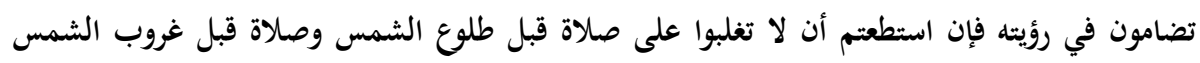
فافعلوا )

Hadis ini menjelaskan sabda Nabi bahwa manusia akan melihat Allah sebagaimana melihat rembulan tanpa ada penghalang. Berdasar hadis ini, al-Ṭabari berani menafsirkan bahwa Allah memungkinkan untuk bisa dilihat oleh makhluk di akhirat nanti.

Pernyataan al-Tabari mengenai kemungkinan Allah bisa dilihat di akhirat nanti dikuatkan lagi dalam menafsiri ayat:

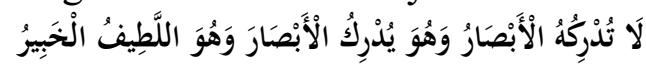

al-Tabari lalu menyinggung ayat yang menyebutkan kemungkinan penduduk sorga bisa melihat Allah di akhirat:

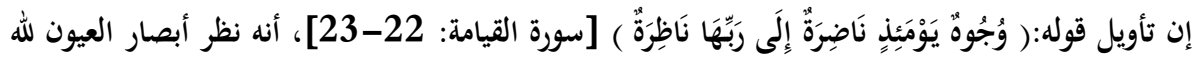

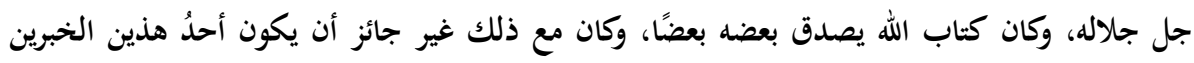

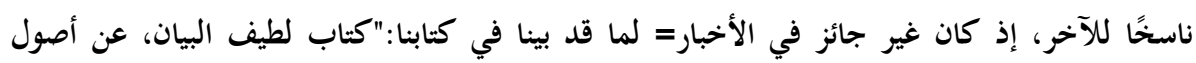

\footnotetext{
${ }^{45}$ Al-Tabarìi, Jàmi' al-Bayān fì Ta’wìl al-Qur' ān, (Bairūt, Muassasah al-Risālah, 2000), Juz 24, Hal. 72.

${ }^{46}$ Muhammad bin Isma'īil Al-Bukhārīi, Shahīh al-Bukhārìi, (Bairūt, Dār Ibnu Kathīr, 1987 M), juz 1, 203.
} 


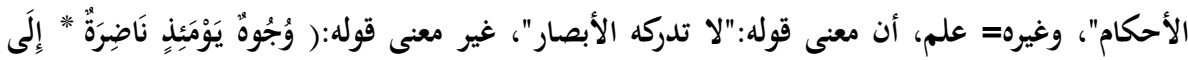

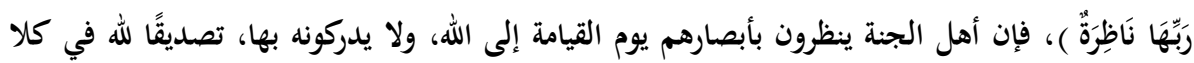

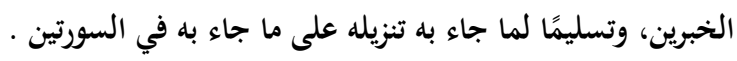

Penafsiran al-Tabari di atas menguatkan pendapatnya bahwa Allah bisa dilihat dengan penglihatan mata, karena menurut beliau, antara makna al-Qur'an secara lahir bahwa Allah bisa dilihat tidak bertentangan dengan hadith Nabi yang diriwayatkan al-Bukhārī, maka dari itu antara yang satu sama yang lain tidak boleh saling menasakh.

Penulis melihat apa yang dilakukan oleh al-Tabarì merupakan langkah yang sesuai dengan metode yang disodorkan ulama 'ulüm alQur'an agar menafsirkan al-Qur'an sesuai dengan kandungan hadis Nabi.

Jadi penafsiran al-Ṭabari bahwa Allah dimungkinkan untuk bisa dilihat di akhirat nanti tujuan utamanya bukan untuk menjustifikasi pendapat Ahlussunnah wa al-Jama'ah, tapi memang berdasarkan dalil hadis Nabi yang valid.

\section{2) Muktazilah}

Sebagai contoh dari tafsir Muktazili, penulis mengambil contoh dari kitab al-Kashshāf karya Zamakhsharī. Zamakhshari menafsirkan ayat 23 dari Surat al-Qiyāmah dengan menyatakan: ${ }^{47}$

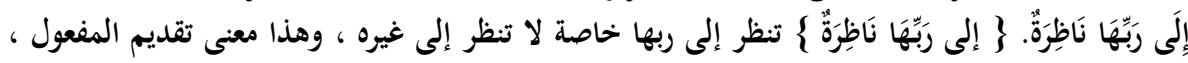

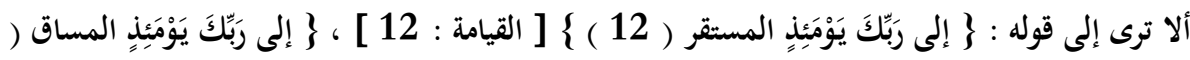

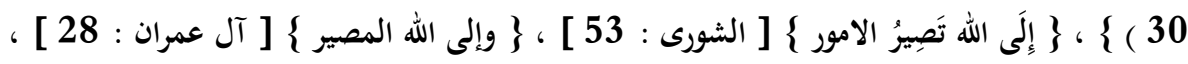

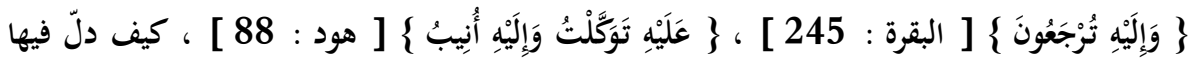

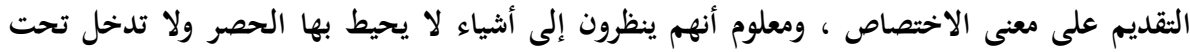

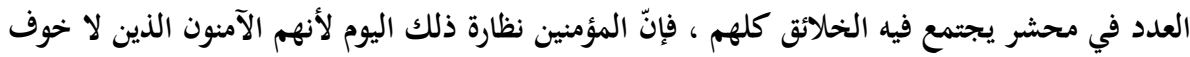

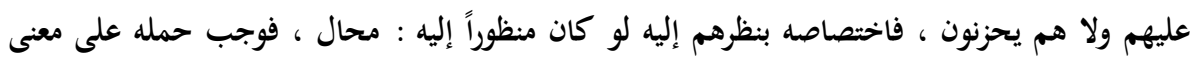

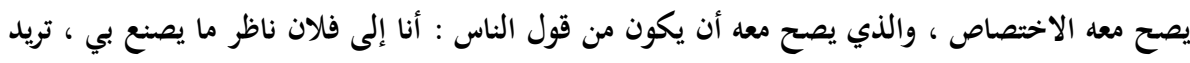

$$
\begin{aligned}
& \text { معنى التوقع والرجاء ـ ومنه قول القائل : }
\end{aligned}
$$

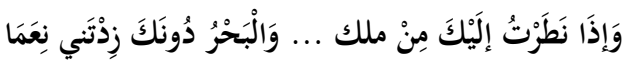

\footnotetext{
${ }^{47}$ Zamakhshari, al-Kashshāf, (Kairo, Maktabah Misr, t.th.), Juz 4, Hal. 509-510.
} 


$$
\begin{aligned}
& \text { وسمعت سروية مستجدية بمكة وقت الظهر حين يغلق الناس أبوابهم ، ويأوون إلى مقائلهم ، }
\end{aligned}
$$

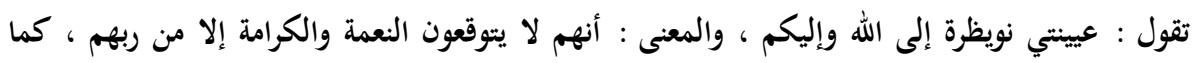

$$
\begin{aligned}
& \text { كانوا في الدنيا لا يخشون ولا يرجون إلا إياه }
\end{aligned}
$$

Zamakhsharì mengartikan kata nāzirah di atas dengan mengharap rahmat dan pahala dari Allah (secara majāzí) dan tidak mengartikannya dengan melihat (haqīîi), karena jika diartikan melihat akan bertentangan dengan pendapat Muktazilah bahwa Allah tidak bisa dilihat meski di akhirat nanti.

Inilah yang oleh ulama 'ulūm al-Qur'an termasuk perkara yang harus dihindari dalam menafsirkan al-Qur'an, yaitu mengedepankan pendapat madhhab dan menjadikan tafsir sebagai justifikasi terhadap pendapat madhhab tersebut. Karena dorongan melegitimasi pendapat madhhab Muktazilahnya, Zamakhshari sampai tidak menghiraukan makna haqi $\bar{q} i$ ayat tersebut yang sebenarnya didukung oleh hadis yang sahịh yang sudah penulis sebut pada pembahasan tafsir al-Tabari.

\section{3) Shī'ah Imāmiya al-Isthnā Ashariyyah}

Penulis mengambil contoh tafsir Shỉ'ah Imāmiya al-Isthnā Ashariyyah ini dari kitab Majma' al-Bayān li 'Ulūm al-Qur'ān karya al-Tibrisi. Ketika al-Ṭibrisi menganut aliran ini, dia juga berpendapat adanya raj'ah, sehingga di saat dia menafsirkan ayat 56 dari Surat alBaqarah dia menyatakan:

$$
\text { ثم بعثناكم من بعد موتكم لعلكم تشكرون }
$$

Sebagian dari kelompok kami menjadikan ayat ini sebagai dalil akan adanya raj'ah, sementara orang yang berpendapat bahwa raj' ah tidak boleh terjadi kecuali pada zaman Nabi sebagai mukjizat dan sebagai bukti kenabiannya merupakan pendapat yang keliru, karena bagi kelompok kami bahkan menurut mayoritas umat mungkin saja terjadi mukjizat melalui kemampuan para imam dan para wali, dan dalil untuk itu ada dalam beberapa kitab-kitab alușūl. ${ }^{48}$

Al-Ṭibrisī menganggap ayat di atas sebagai dalil yang menguatkan adanya raj'ah, yaitu paham yang menganggap bahwa setelah munculnya al-mahdi al-muntazar, Nabi Muhammad, Ali bin Abi Ṭālib, Hasan, Husain, dan para imam akan hidup kembali, bahkan

\footnotetext{
${ }^{48}$ Al-Tibrisì dalam Al-Zahabī, al-Tafsìr wa al-Mufassirūn, (Kairo: Dār al-Hadith, 2005), II. 96.
} 
musuh-musuh mereka pun seperti Abu Bakar dan Umar juga akan hidup kembali hingga para imam bisa menghukum mereka.

Dari penafsiran al-Tibrisi ini, bisa disimpulkan dua hal. Pertama, mukjizat bukan hanya terjadi pada masa nabi saja, tapi setelah masa nabi pun mukjizat bisa terjadi. Kedua, mukjizat bukan hanya untuk nabi, tapi para imam Shi'ah-pun bisa juga mendapat mukjizat.

Hal ini jelas bertentangan dengan definisi mukjizat sendiri, yang dalam al-Itqān disebutkan bahwa mukjizat adalah kemampuan di luar kebiasaan yang disertai tantangan dan tidak dapat dilawan. ${ }^{49}$ Sementara Mannā' Khalil al-Qatțān menyebutkan bahwa mukjizat adalah menampakkan kebenaran nabi dalam pengakuannya sebagai seorang utusan (utusan) dengan menampakkan kelemahan lawanlawannya. ${ }^{50}$

Ini pengertian mukjizat yang digariskan oleh para ulama 'ulūm al-Qur'an, jika dikaitkan dengan penafsiran al-Ṭibrisì tentang ayat di atas, maka dia secara nyata mengakui para imam Shī'ah memiliki kedudukan yang sama dengan para nabi, sebab para imam mereka memiliki kelebihan yang diberikan kepada nabi, yaitu berupa mukjizat, yang merupakan bukti kenabian.

Jika yang dimaksud al-Ṭibrisi dalam penafsiran ayat tersebut adalah kemampuan di luar kebiasaan dan bukan sebagai bukti kenabian, maka menyebutkannya dengan istilah mukjizat tidaklah tepat, karena para ulama menyebut hal itu sebagai karāmah.

\section{Epilog}

Setelah membahas tafsir dari aspek kecenderungannya (aliran) bisa dipastikan bahwa setiap aliran dalam Islam memiliki penafsiran sendiri-sendiri. Perbedaan penafsiran ini menjadi maklum mengingat latar belakang dan motivasi penafsiran mereka juga berbeda-beda. Ada yang menafsirkan al-Qur' an karena memang ingin menjelaskan makna al-Qur'an sesuai dengan makna yang diinginkan oleh Allah, sehingga metode atau cara yang ditempuh untuk mencapai hal tersebut sesuai dengan standar yang disodorkan para ulama 'ulūm alQur' an, karena memang tidak ada motivasi lain yang tersembunyi.

\footnotetext{
${ }^{49}$ Jalaluddin al-Suyūṭi, al-Itqan fì 'Ulūm al-Qur'ān, (Beirut: Dār al-Fikr, 1951), II, 148.

${ }^{50}$ Mannā' Khalil al-Qaț̣̄an, Studi Ilmu-ilmu Qur'an, terj. Mudhakir AS. (Jakarta: Litera Antarnusa, 2001), 371.
} 
Namun, di samping itu, ada juga orang yang menafsirkan alQur'an hanya untuk mencari justifikasi terhadap pendapat-pendapat madhhab atau golongannya, sehingga tidak heran ketika metode maupun cara yang mereka tempuh tidak sesuai dengan standar baku dalam menafsirkan al-Qur'an.

Pembagian seperti ini dalam kajian ilmu al-Qur'an disebut dengan tafsir bi al-ra'yi al-mahmūd dan tafsir bi al-ra'yi almadhmüm. Tidak sulit untuk mengetahui perbedaan kedua penafsiran ini, karena para ulama terutama ulama 'ulūm al-Qur'an telah memberi baro-meter atau standar penafsiran al-Qur'an, jika cara atau metode yang ditempuh oleh seorang mufassir sesuai dengan ketentuan tersebut, maka bisa dipastikan penafsirannya termasuk penafsiran yang baik atau tafsir bi al-ra'yi al-mahmūd, begitu pula sebaliknya.

\section{Daftar Pustaka}

Al-Baghdādì,Abdul Qāhir. al-Farqu baina al-Firāq wa Bayān alFirqah al-Nājiyah Minhum, Kairo: Maktabah Ibnu Sinā, 1988 M.

Al-Bukhārī, Muhammad bin Isma'ìl. Shahīh al-Bukhāri, Bairūt, Dār Ibnu Kathir, 1987 M.

Al-Ifrịqụ, Ibn Manzūur. Lisān al-'Arab. Beirut: Dār al-Fikr, 1990 M.

Al-Qațān, Mannā' Khalil. Studi-studi Ilmu al-Qur'an, trj. Mudzakir AS., Jakarta: Litera Antarnusa, 2001 M. Cet. VI.

Al-Ṣābūnì, M. Ali. al-Tibyān fì 'Ulūm al-Qur'ān, Terj. M. Choirul Umar. Bandung: PT. al-Ma’ārif, t.th.

Al-Shiddieqy, M. Hasbi. Sejarah dan Pengantar Ilmu alQur'an/Tafsir. Jakarta: Bulan Bintang, 1954 M.

Al-Suyựtịi, Jalāluddìn. al-Itqān fì 'Ulūm al-Qur'ān, Beirut: Dār alMa'rifah, t.th.

Al-Ṭabari, Jāmi' al-Bayān fì Ta'wìl al-Qur'ān, Bairūt, Muassasah alRisālah, $2000 \mathrm{M}$.

Al-Žahabī, Muhammad. al-Tafsìr wa al-Mufassirūn, Kairo: Dār alHadith, $2005 \mathrm{M}$.

Al-Zarqānī, Abdul Aẓim. Manāhil al-'Irfān, Kairo: Maṭba'ah Shubrā, $1359 \mathrm{H}$.

Anwar, Rosihon dan Abdul Rozak. Ilmu Kalam, Bandung: CV Pustaka Setia, 2009 M. Cet. IV. 
Anwar, Rosihon. Samudera al-Qur'an Bandung: CV. Pustaka Setia, $2001 \mathrm{M}$.

Asmuni, M Y usran. Ilmu Tauhid, Jakarta: PT Raja Grafindo Persada, $1996 \mathrm{M}$.

Baidan, Nashruddin. Wawasan Baru Ilmu al-Qur'an, Yogyakarta: Pustaka Pelajar, $2011 \mathrm{M}$.

Faudah, Mahmūd Basūnī. Tafsir-tafsir al-Qur'an: Perkenalan dengan Metodologi Tafsir, terj. M. Mochtar Zoerni dan Abdul Qodir Hamid Bandung: Pustaka, $1987 \mathrm{M}$.

Hanafî, Hasan. al-Yamīn wa al-Yasār fì fikr al-Dīnī, Kairo: Madbūli, $1989 \mathrm{M}$.

http://kbbi.web.id/

Khaldūn, Abdurrahman bin Muhammad. Muqaddimah Ibnu Khaldūn Kairo: al-Taufiqiyah, t.th.

Sà'ì, Muhammad Nu'aīm Muhammad Hānì. al-Qānūn fì 'Aqāid alFiraq wa al-Madhāhib al-Islāmiyah, Kairo: Dār al-Salām, 2007 M.

Zahrah, Muhammad Abū. Tärỉkh al-Jadal, Kairo: al-'Ulūm, 1934 M.

Zamakhshari, al-Kashshäf, Kairo, Maktabah Misr, t.th. Juz 1. 